\title{
Android Based Implementation of Location-Based Service in Reporting Waste Existence
}

\author{
Najirah Umar ${ }^{1}$, Billy Eden William Asrul ${ }^{2}$ \\ ${ }^{1,2}$ Department of Technical Information, Sekolah Tinggi Manajemen Informatika dan \\ Komputer Handayani, Indonesia, 90321 \\ \{najirah@handayani.ac.id ${ }^{1}$, billy@handayani.ac.id²\}
}

\begin{abstract}
Reporting the existence of waste is an essential thing in big cities because if the waste is not disposed of quickly it will cause new problem such as disease. One of the things to be done is by increasing community participation by utilizing technologies such as smartphones to report the existence of waste. Location-Based Service (LBS) uses GPS technology in its application. Besides being able to find out the user's position, the LBS application can also determine the position of the reported waste. If a user can maximize this technology, then he or she can help out waste workers to retrieve waste by solely reporting the waste location. This research produces a mobile application that can locate and display the user's and waste position. This application is the integration of google map services in determining the path between users and a place.
\end{abstract}

Keywords: $L B S$, GPS, Waste, Android

\section{Introduction}

The development of mobile phone device technology is quite rapid. Besides as voice communication tools and messaging tools, it also functions as location search tools. Along with the increasing need for new features for mobile phones, making vendors develop new technologies for each of their products. One of the technologies applied in today's mobile phone devices is the Global Positioning System (GPS) technology[1]. By utilizing GPS, users can find out where they are in real time. The LBS application will look for a route to connect the user's position to a place [2].

To get information about the presence of waste, a janitor usually go around the work area or go to the urban village to report the existence of uncleaned waste. However, doing those ways above certainly take time and might give inaccurate information about the waste location. This condition can be resolved by having an application that can be used to report, find out the path to where the waste is located. LBS implementation is one solution to overcome this particular situation.

It will not be difficult for the janitor to pick up the waste when they use this application. As the apps open, waste position will be visible, and then the janitor will follow the route shown by GPS starting from the nearest location. Moreover, a mobile phone or smartphone device is a practical tool to report the existence of waste because it is easier for the community who is always on the move. 
A location-based service is an information service that can be accessed by a mobile phone. Location Based Service System, or better known as Location-Based Services (LBS), combines the process of mobile service with the geographical position of its users. The target position might be the Location-Based Services user itself or another entity that is incorporated in service [2].

Two types of services can be used in Location-Based Services to obtain the user's position, namely by using a network cell position or by GPS or aGPS. From these two ways, the user's position can be located in the form of latitude and longitude coordinates. Latitude is a representation of the North-South direction, while longitude is a representation of the EastWest direction. In addition to the user's position, Location-Based Services can also be seen from the service provided as an interactive service [3]. Concerning services provided, Location-Based Services can be divided into two, namely reactive Location-Based Services and proactive Location-Based Services. Reactive Location-Based Services are services that are only active if there is an action taken by the user. Services that will only give if there are requests from users. While proactive Location-Based Services is a service that will always provide information to users even though the user does not make requests for services. Location searches mobile application that can guide and provide information about a place that can be accessed anytime and anywhere [4].

One operating system for mobile smartphones currently available is the Android. It is an open source operating system built on 2.6 Linux Kernel. One of the advantages of this opensource operating system is that third-party applications can access all of the resources owned by the smartphone, without differentiating them from the core applications of smartphones [4]. Android also makes developer easy to develop applications like LBS apps because Android provides access and integration with google map services.

The advancement of wireless telecommunications technology and the mass integration of wireless communication devices to the public have created the next generation of computing, the mobile generation [5].

Research on the implementation of location-based services has been widely carried out for location-based public services, especially the location of public facilities, providing information in real time using android mobile [6], location-based information services for tour guides [7] Public service location-based services, location-based intelligent transportation [8] [15][9], location-based communication services [9]. The research that is being carried out at this time is in addition to utilizing Location Based Service but also utilizing cameras that can be used to take pictures of waste then send servers, making it easier for the public to report the existence of waste. Previous research on location-based services for shared facilities, such as ATMs.

The contribution of this research is to invite society to utilize the mobile phone to maintain the environment especially cleanliness. Moreover as one source of teaching materials to make location-based applications for students.

\section{Material and Methods}

The methodology used is (Rational Unified Process) RUP. This method is an iterative system development stage specifically for object-oriented programming, here is a picture of the live or phase flow found in the RUP method [10]. 


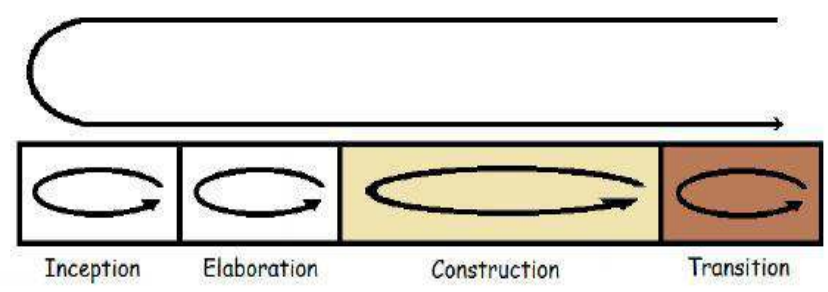

Figure 1. RUP Life Algorithm

The explanation of the four working stages of the RUP is as follows:

\section{a. Inception Phase (Beginning)}

During the initial phase, researchers build design for the system and limit the scope. To achieve this, researchers identify all external entities with the system that will interact and determine the nature of this interaction. It involves identifying all use cases and describing significant ones. Design includes success criteria, risk assessment, and estimated resources needed.[11]

\section{b. Elaboration Phase (Expansion / Planning)}

This stage focuses more on planning system architecture. This stage can also detect whether the desired system architecture can be created or not, detecting risks that might occur from the architecture created. This stage is also more about the analysis and system design as well as the implementation of systems that focus on prototype systems. [12]

The system design used is object oriented design (Object Oriented Analysis and Design) which consists of: Use Case Diagram. It is a modeling for the information system behavior to be created. Activity Diagram describes the work flow or activity of a system or business processes.[13]

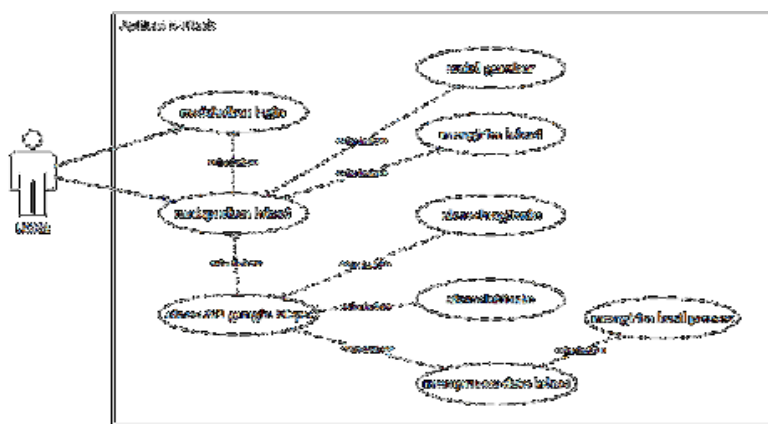

Figure 2. Use Case Application Diagram

The community as the primary user in the system must send the location of the waste stack found using the e-Trash application, then take pictures with the smartphone and send the longitude and latitude automatically to the server via smartphone GPS. Before reporting the existence of waste one must register then log in as user. 


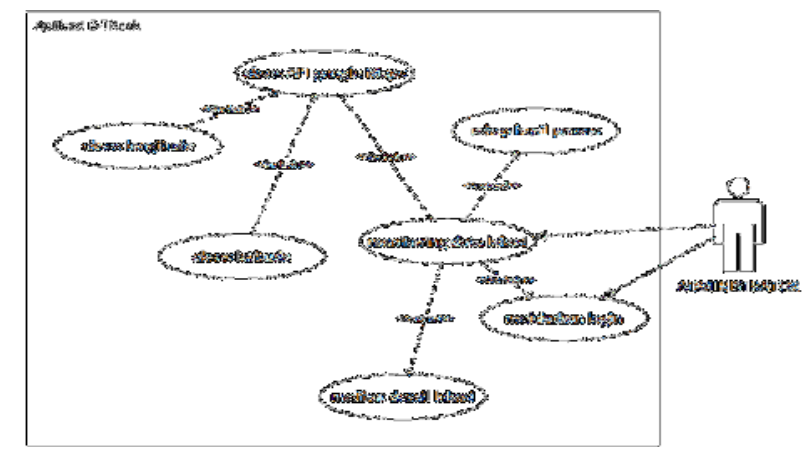

Figure 3. Use case Application Admin

The system administrator as the second actor functions as monitor of the results of reports from the public. It summarizes results of the report by looking at all the details of the location of the waste stack, which begins with the admin login.

\section{c. Construction Phase}

This stage focuses on developing system components and features. This stage is more about implementing and testing systems that focus on implementing software in the program code. This stage produces software products which are the requirements of the Initial Operational Capability Milestone or initial operational capability limits/milestones.[14]

\section{d. Transition Phase}

This stage is more about the deployment or installation of the system, so that the user can understand it. This stage produces software which are the requirements of the Initial Operational Capability Milestone or the initial operational capability limits. Activities at this stage include user training, system maintenance, and testing whether they meet user expectations.

\section{Results and Discussion}

This application is a media to help the community to report waste which uses Location Based Service Technology (LBS). This software is an Android version which primarily used by urban communities. The database that will be used is a prototype and can run on devices that have certain specifications using an internet connection.

Making this Android-based trash application starts by analyzing system requirements then proceed designing the user interface. The next stage is implementing the user interface into a system that can be read by the system (coding). After that, the application is tested to find out whether the application has errors or not. The results obtained are as follows: 
a. User Display Menu
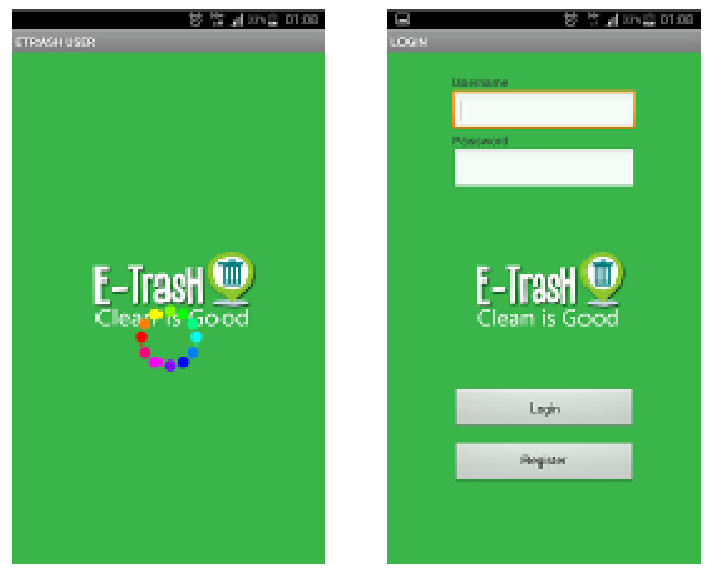

Figure 4. User Application

Before reporting the existence of waste, a user must first log in, then take a picture and send the longitude and latitude automatically to the server via smartphone GPS. After that the menu will appear as follows:

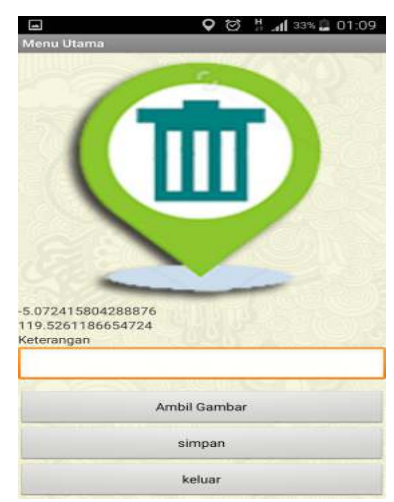

Figure 5. Pictures Taking Menu

The interface display in the picture above is already arranged the button layout, text field, menu or other visual components, so users will not be confused to use this application. Photos of location, data longitude, and latitude data are sent simultaneously to the server.

After taking pictures of the existence of waste, the menu will then appear to allow user send images by first selecting them that stored in the camera or SD Card as follows: 


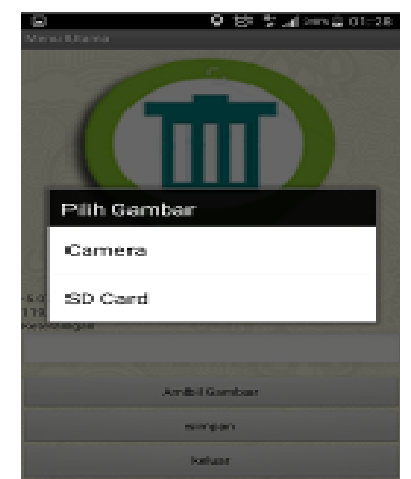

Figure 6. Selects Image Storage Menu

After selecting the saved image position, a menu will appear to ascertain whether the image will be sent to the server or not as follow in figure 7.

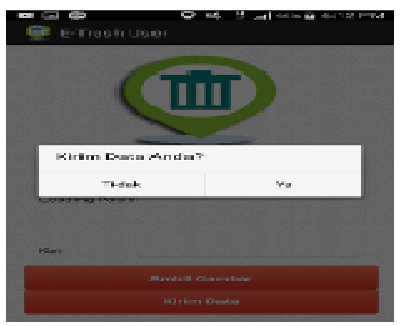

Figure 7. Send Image Menu

After the process of sending images to the server done, a menu will appear to exit the application, As figure 8 below:
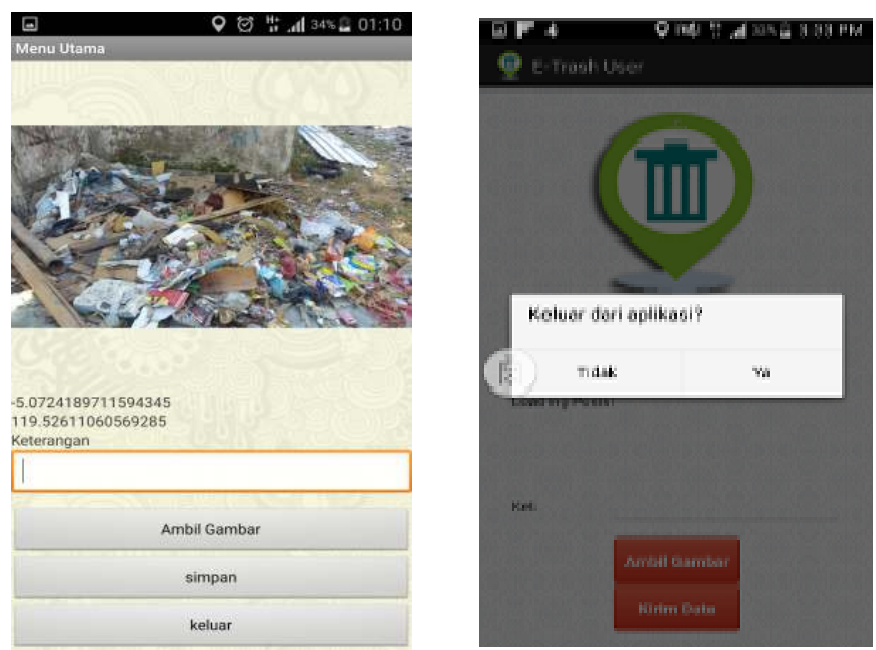

Figure 8. Exit Menu From the User Application 
b. Display Server Application as the second Actor

The system administrator as the second actor monitor reports from the public and summarize the results by looking at all the details of the location of the waste, which begins with the admin login, as Figure 9 below:

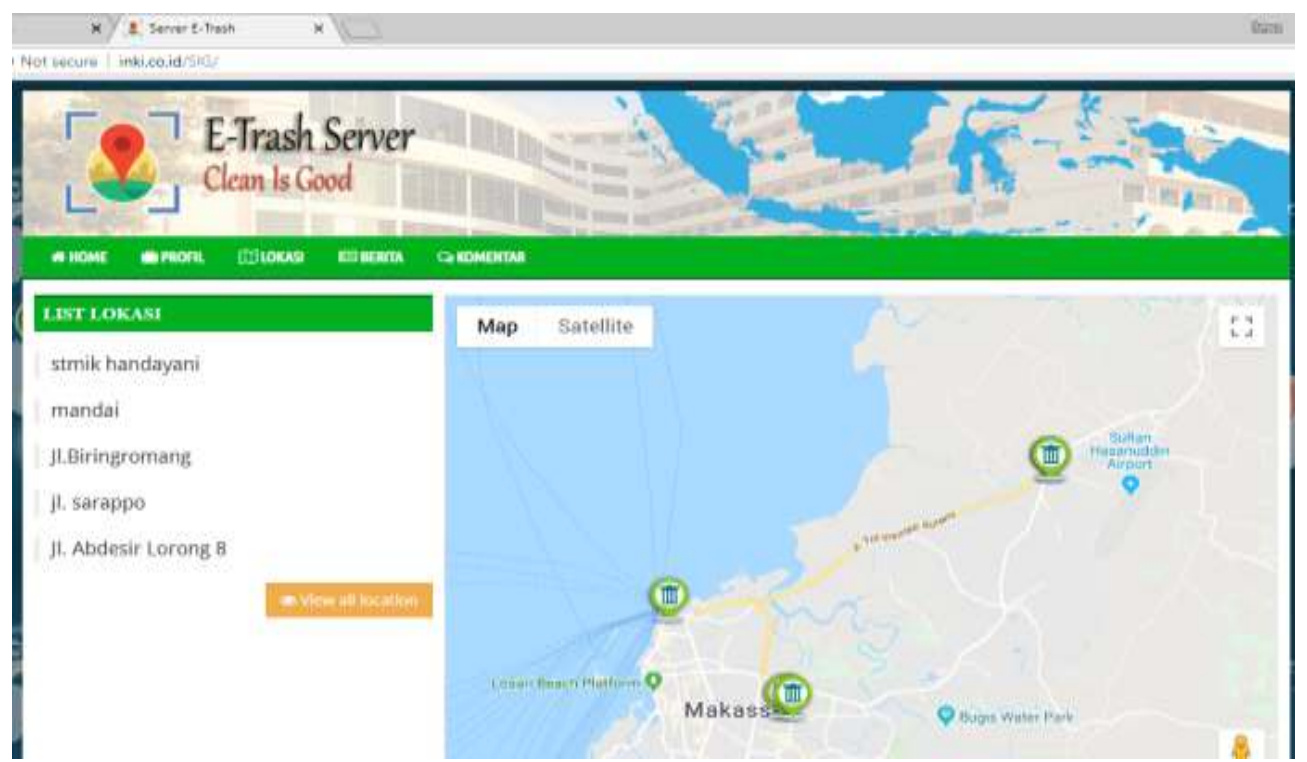

Figure 9. Main Server Application Menu.

Applications on the part of the server that has been designed can run on personal computers. The first thing to do at this stage is to choose the application installed on the personal computer and select the monitoring menu, the server functions to monitor the data of the process between the user and the results of the janitor process as another actor. The server also accesses the Google MAPS API to see the data longitude and latitude of the process that has been sent from the client application.

The E-trash symbol markers on the map indicate the position of the waste that has been sent by the community and the process that has been carried out by the actors who have performed service to the community reports based on the location indicated in the e-trash application. In the case of the location-based server function (LBS), it will work if the actor admin can see the position of the waste and the position of the waste that has been cleaned, and the actor in seeing the position of the nearest waste from the position of the officer to be served and report if it has done the cleaning process waste.

\section{c. Testing}

1. Testing a Database Connection

To view the data transmission connection from the Mobile Application to the database server. 
Table 1. Data Delivery Connection Testing Module

\begin{tabular}{|l|l|l|l|l|l|}
\hline NO & Description & $\begin{array}{l}\text { Testing } \\
\text { Procedure }\end{array}$ & Input & $\begin{array}{l}\text { Expected } \\
\text { Output }\end{array}$ & Result \\
\hline 1 & $\begin{array}{l}\text { Delivery of } \\
\text { Longitude } \\
\text { and Latitude } \\
\text { data from } \\
\begin{array}{l}\text { User to } \\
\text { Server } \\
\text { Applications }\end{array}\end{array}$ & $\begin{array}{l}\text { Activate GPS } \\
\text { and Run User } \\
\text { Application. }\end{array}$ & $\begin{array}{l}\text { Longitude } \\
\text { and Latitude } \\
\text { of the User } \\
\text { application }\end{array}$ & $\begin{array}{l}\text { Display the } \\
\text { position of } \\
\text { data on the } \\
\text { Trash } \\
\text { Location } \\
\text { Server Map }\end{array}$ & $\begin{array}{l}\text { Shown } \\
\text { Map Server } \\
\text { Location } \\
\text { according to } \\
\text { Longitude } \\
\text { and Latitude } \\
\text { sent by User }\end{array}$ \\
\hline 2 & $\begin{array}{l}\text { Data } \\
\text { transmission } \\
\text { for Longitude } \\
\text { and Latitude } \\
\text { From Server } \\
\text { Application } \\
\text { to Officer } \\
\text { Application }\end{array}$ & $\begin{array}{l}\text { Activate GPS } \\
\text { and Run the } \\
\text { Application }\end{array}$ & $\begin{array}{l}\text { Longitude } \\
\text { and Latitude } \\
\text { from the } \\
\text { Server } \\
\text { application }\end{array}$ & $\begin{array}{l}\text { Position of } \\
\text { data appears } \\
\text { on the Trash } \\
\text { Location } \\
\text { Officer Map } \\
\text { according to } \\
\text { the position } \\
\text { on the server } \\
\text { map }\end{array}$ & $\begin{array}{l}\text { Map Location } \\
\text { Staff } \\
\text { according to } \\
\text { the Longitude } \\
\text { and Latitude } \\
\text { sent by the } \\
\text { server }\end{array}$ \\
\hline
\end{tabular}

2. System Access Time Testing Module

This test is intended to see the response time needed by the system to display content based on user requests.

Table 2. Testing of System Access Time (Response Time)

\begin{tabular}{|c|c|c|c|c|c|}
\hline NO & Description & Provider & Network & Result & $\begin{array}{ll}\text { Access } & \text { Time } \\
\text { (second) } & \end{array}$ \\
\hline \multirow[t]{3}{*}{1} & \multirow{3}{*}{$\begin{array}{l}\text { Display the Longitude } \\
\text { and Latitude of the } \\
\text { smartphone GPS to the } \\
\text { User Application }\end{array}$} & 3 & $4 \mathrm{G}$ & \multirow{3}{*}{$\begin{array}{l}\text { Display Latitude } \\
\text { and Longitude } \\
\text { Coordinates }\end{array}$} & $0.092 \mathrm{~s}$ \\
\hline & & Indosat & $4 \mathrm{G}$ & & $0.081 \mathrm{~s}$ \\
\hline & & Telkomsel & $4 \mathrm{G}$ & & $0.078 \mathrm{~s}$ \\
\hline \multirow[t]{3}{*}{2} & \multirow{3}{*}{$\begin{array}{l}\text { Display the Longitude } \\
\text { and Latitude of the } \\
\text { smartphone GPS to the } \\
\text { User Application }\end{array}$} & 3 & $3 \mathrm{G}$ & \multirow{3}{*}{$\begin{array}{l}\text { Display } \begin{array}{r}\text { Latitude } \\
\text { and Longitude }\end{array} \\
\text { Coordinates }\end{array}$} & $0.122 \mathrm{~s}$ \\
\hline & & Indosat & $3 \mathrm{G}$ & & $0.117 \mathrm{~s}$ \\
\hline & & Telkomsel & $3 \mathrm{G}$ & & $0.113 \mathrm{~s}$ \\
\hline \multirow[t]{2}{*}{3} & \multirow{2}{*}{$\begin{array}{l}\text { Load the Main Server } \\
\text { Page Map access URL } \\
\text { (inki.co.id/SIG) }\end{array}$} & HINET/IM2 & $\begin{array}{l}4 \mathrm{G} / \\
\mathrm{Mbps}\end{array}$ & \multirow{2}{*}{$\begin{array}{l}\text { Display the Main } \\
\text { Menu and Maps } \\
\text { Server Map }\end{array}$} & $1.94 \mathrm{~s}$ \\
\hline & & $\begin{array}{l}\text { Telkom/Speed } \\
\text { y }\end{array}$ & $3 \mathrm{Mbps}$ & & $1.63 \mathrm{~s}$ \\
\hline \multirow[t]{3}{*}{4} & \multirow{3}{*}{$\begin{array}{l}\text { Display Routes based on } \\
\text { Coordinates from server } \\
\text { to application officer }\end{array}$} & 3 & $4 \mathrm{G}$ & \multirow{3}{*}{$\begin{array}{l}\text { Display Latitude } \\
\text { and Longitude } \\
\text { Coordinates }\end{array}$} & $4.43 \mathrm{~s}$ \\
\hline & & Indosat & $4 \mathrm{G}$ & & $4.51 \mathrm{~s}$ \\
\hline & & Telkomsel & $4 \mathrm{G}$ & & $3.28 \mathrm{~s}$ \\
\hline \multirow[t]{3}{*}{5} & \multirow{3}{*}{$\begin{array}{l}\text { Displays Coordinate- } \\
\text { based Paths from server } \\
\text { to application officer }\end{array}$} & 3 & $3 G$ & \multirow{3}{*}{$\begin{array}{l}\text { Display Latitude } \\
\text { and Longitude } \\
\text { Coordinates }\end{array}$} & $5.122 \mathrm{~s}$ \\
\hline & & Indosat & $3 \mathrm{G}$ & & $5.117 \mathrm{~s}$ \\
\hline & & Telkomsel & $3 G$ & & $4.43 \mathrm{~s}$ \\
\hline
\end{tabular}




\section{Conclusion}

1. With this application, it helps the community to report the existence of waste easily by utilizing smartphones.

2. The speed of access time depends on the provider and the type of network used.

3. The accuracy of the position of the user received by the GPS can miss a few meters from the actual position because the positioning depends on the GPS hardware of the user's smartphone.

\section{Acknowledgements}

We thank to DPRM Ristekdikti for supporting this research.

\section{References}

[1] S. Sukaphat, "An implementation of location-based service system with cell identifier for detecting lost mobile," Procedia Comput. Sci., vol. 3, pp. 949-953, 2011.

[2] B. N. Jagdale and J. W. Bakal, "Controlled Broadcast Protocol for Location Privacy in Mobile Applications,” Phys. Procedia, vol. 78, no. December 2015, pp. 782-789, 2016.

[3] M. Han, J. Wang, M. Yan, C. Ai, Z. Duan, and Z. Hong, "Near-Complete Privacy Protection: Cognitive Optimal Strategy in Location-Based Services," Procedia Comput. Sci., vol. 129, pp. 298-304, 2018.

[4] E. Isabela et al., "NYAM: An Android Based Application for Food Finding Using GPS," Procedia Comput. Sci., vol. 135, pp. 393-399, 2018.

[5] G. Li, Y. Yin, J. Wu, S. Zhao, and D. Lin, "Trajectory Privacy Protection Method Based on Location Service in Fog Computing," Procedia Comput. Sci., vol. 147, pp. 463-467, 2019.

[6] D. Su, J. Liu, W. Wang, X. Wang, X. Du, and M. Guizani, "Discovering communities of malapps on Android-based mobile cyber-physical systems," Ad Hoc Networks, vol. 80, pp. 104-115, 2018.

[7] T. Dimitriou and N. Al Ibrahim, “I wasn't there'-Deniable, privacy-aware scheme for decentralized Location-based Services," Futur. Gener. Comput. Syst., vol. 86, pp. 253-265, 2018.

[8] K. Lee, J. Lee, and M. P. Kwan, "Location-based service using ontology-based semantic queries: A study with a focus on indoor activities in a university context," Comput. Environ. Urban Syst., vol. 62, pp. 41-52, 2017.

[9] J. Lin, J. Niu, H. Li, and M. Atiquzzaman, "A Secure and Efficient Location-based Service Scheme for Smart Transportation," Futur. Gener. Comput. Syst., vol. 92, pp. 694-704, 2018.

[10] S. S. Rajasekar and C. Palanisamy, "Optimized location-based service selection for QoS improvement in wireless networks," Comput. Electr. Eng., vol. 64, pp. 277-287, 
2017.

[11] V. Sucasas et al., "A privacy-enhanced OAuth 2.0 based protocol for Smart City mobile applications," Comput. Secur., vol. 74, pp. 258-274, 2018.

[12] Z. Sun et al., "GeoFairy: Towards a one-stop and location based Service for Geospatial Information Retrieval," Comput. Environ. Urban Syst., vol. 62, pp. 156$167,2017$.

[13] M. W. Wilson, "Location-based services, conspicuous mobility, and the locationaware future," Geoforum, vol. 43, no. 6, pp. 1266-1275, 2012.

[14] S. Y. Yang and C. L. Hsu, "A location-based services and Google maps-based information master system for tour guiding," Comput. Electr. Eng., vol. 54, pp. 87$105,2016$.

[15] S. Zhang, X. Li, Z. Tan, T. Peng, and G. Wang, "A caching and spatial [Formula presented]-anonymity driven privacy enhancement scheme in continuous locationbased services," Futur. Gener. Comput. Syst., vol. 94, pp. 40-50, 2019. 